by Barbara Wohlfarth ${ }^{1}$, Svante Björck ${ }^{2}$, Svend Funder ${ }^{3}$, Michael Houmark-Nielsen $^{4}$, Ólafur
Ingólfsson $^{5}$, Juha-Pekka Lunkka $^{6}$, Jan Mangerud $^{7}$, Matti Saarnisto $^{8}$, and Tore Vorren

\title{
Quaternary of Norden
}

1 Department of Geology and Geochemistry, Stockholm University, SE-106 91 Stockholm, Sweden. E-mail: Barbara@geo.su.se

2 GeoBiosphere Science Centre, Quaternary Sciences, Sölvegatan 12, SE-223 62 Lund, Sweden. E-mail: Svante.Bjorck@geol.lu.se

3 Geological Museum, University of Copenhagen, Øster Voldgade 5-7, DK-1350 Copenhagen K, Denmark. E-mail: svf@snm.ku.dk

4 Institute of Geography and Geology, University of Copenhagen, Østervoldgade 10, Dk-1350 København K, Denmark.E-mail: michaelh@geol.ku.dk

5 Department of Geology, University of Iceland, Askja, Is-101 Reykjavík, Iceland. E-mail: oi@hi.is

6 Institute of Geosciences, P.O. Box 3000, FI-90014 University of Oulu, Finland. E-mail: juha.pekka.lunkka@oulu.fi

7 Department of Earth Science and the Bjerknes Centre for Climate Research, University of Bergen, Allégatan 41, N-5007 Bergen, Norway.

E-mail: Jan.Mangerud@geo.uib.no

8 Finnish Academy of Science and Letters, Mariankatu 5, FI-00170 Helsinki, Finland. E-mail: matti.saarnisto@acadsci.fi

9 Department of Geology, University of Troms $\varnothing$, Dramsveien 201, N-9037 Troms $\varnothing$, Norway. E-mail: Tore.Vorren@matnat.uit.no

The Nordic countries have experienced multiple glaciations and intervening interglacials during the last ca. 2.5-3 million years. Although evidence from Greenland and Iceland shows that ice sheets started to expand some time before $3 \mathrm{Ma}$, little is known about the glaciations and intervening interglacials older than the last Glacial Maximum due to repeated phases of glacial erosion and reworking. The extensive Saalian glaciation (c. $140 \mathrm{ka} \mathrm{BP}$ ) contributed to high sea levels in Greenland and in the Baltic area during the early part of the last interglacial (Eemian). Temperatures were about $5{ }^{\circ} \mathrm{C}$ higher during the Eemian than they are today and the Greenland ice sheet was reduced to about half of its present size, causing globally higher sea levels than we have today. Ice extent in Fennoscandia was restricted during early Weichselian stadials, but middle Weichselian ice advances in Scandinavia reached as far as Denmark. During the Last Glacial Maximum, large ice sheets were present in all Nordic countries and coalesced with neighboring ice sheets. Deglaciation commenced around 17-15 ka BP in most areas and was promoted by rapidly rising global sea level and glacial isostasy. The Younger Dryas cold event(c. 12.6-11.5 ka $B P)$ is seen as a short-term re-advance, still-stand or fluctuation of land-based ice sheet margins. Around 7-9 ka BP ice sheets had disappeared or had attained their present size. While uplift is still going on in some regions, others are subject to submergence. The different stages of development of the Baltic Sea are an example of how the intricate interplay between glacial eustasy and isostasy influences sedimentation, basin size and drainage patterns.

\section{Introduction}

The Nordic countries have experienced multiple glaciations and interglacials during the course of the Quaternary time period, i.e. the last c. 2.5 million years (Ma). Ice sheets and glaciers shaped much of the present-day landscapes and isostatic rebound, combined with eustatic sea level changes left profound traces. The paleoenvironmental and paleoclimatic development during the early and middle part of the Quaternary, i.e. prior to the Last Glacial Maximum

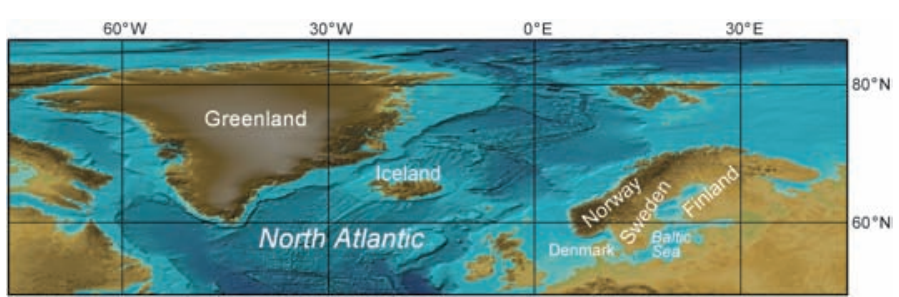

Figure 1 Map of the Nordic countries (reproduced with permission of Martin Jakobsson, Stockholm University).

(LGM, c. 21 ka BP [thousand years before present]) is only poorly known since the ice sheets successively eroded and reworked older, underlying strata. In areas where the LGM ice sheet base was frozen to its bed, older glacial landforms are, however, well preserved and offer insight into earlier histories of ice sheet advance and retreat. The different parts in this review present the present state of knowledge regarding the Quaternary in the Nordic countries (Figure 1) and are organised and written by those most familiar with the regions (Greenland, Iceland, Finland) and/or topics (ice sheet behaviour and Baltic Sea development).

\section{Greenland during the Quaternary}

The Greenland ice sheet, which now occupies $80 \%$ of the land, may have started to grow during Late Eocene times (Eldrett et al., 2007) and the glacial landscape with its fjords and glacial troughs was probably formed before the onset of the Quaternary. Till exposures on land, ice-rafted debris in the Greenland Sea, and seismic studies on the shelf show that the ice sheet expanded onto the shelf of northern and eastern Greenland at the beginning of the Quaternary. However, the trough mouth fans, which were built along the shelf break, are much smaller than their Norwegian counterparts (see chapter on Norway), which indicates that the hallmark of the Greenland ice sheet-its stability and inertia towards climate change-has prevailed throughout the Quaternary. The ice sheet apparently disappeared during Early Quaternary interglacials, as inferred from the sediment succession of the Kap København Formation (c. 2.4 Ma), a sequence with a unique record of terrestrial and shallow marine environments close to the northern tip of Greenland (Funder et al., 2001). This may have been the last time when Greenland was ice free, although DNA analyses of basal ice in a core from central Greenland indicate that this site and probably large areas in southern Greenland also were ice free, and covered by forest at some time between 0.4 and 0.8 Ma (Willerslev et al., 2007). Apart from this, very little information exists about Greenland's environment during the first 2 Ma of the Quaternary. 
Glacio-isostatic uplift after the melting of the extensive Saalian ice sheet left wide-spread Early Eemian marine sediments on land in northwest and east Greenland. The rich marine faunas bear evidence of stronger than Holocene advection of warm Atlantic waters along the Greenland coasts. Terrestrial plant remains indicate summer temperatures, as much as $5^{\circ} \mathrm{C}$ warmer than present (Cape-Last Interglacial Project Members 2006). Melting of the Saalian ice sheet is estimated to have contributed $2-4 \mathrm{~m}$ to the Eemian high sea level, which was 5-7 m higher than during the Holocene and implies that the ice sheet was 33-50\% smaller than at present (e.g. Otto-Bliesner et al., 2006) (Figure 2a). During the LGM the Greenland ice sheet covered an area of c. 3 million $\mathrm{km}^{2}$, i.e. $40 \%$ more than today (Funder et al., 2004). In the north it merged with the Laurentide ice sheet of North America, and in the southwest, its margin was close to the western margin of the Icelandic ice cap (Figure 2b). Ice break up began c. $15 \mathrm{ka}$ BP with the clearance of the shelves and may have been triggered by sea level rise. Large plough marks produced by ice bergs with a keel depth of $950 \mathrm{~m}$ off West and East Greenland testify to this phase of deglaciation (Kuijpers et al., 2007). Before the Younger Dryas (12.8-11.5 ka BP) the shelf and major inlets had apparently been cleared of ice. However, athough ice cores distinctly show the Younger Dryas cooling, the response of the ice margin is not clear. In some areas it may have advanced, while it retreated in others (Denton et al., 2005; Jennings et al., 2006). During the Early Holocene (c. $11.3 \mathrm{ka} \mathrm{BP}$ ), retreat was under way in all parts, but the duration, amount, and rate varied from area to area (Bennike and Björck, 2002), as shown by the varying altitudes of the marine limits. Maximum altitudes of $160 \mathrm{~m}$ occurred in coastal West Greenland, while marine limits in the northwest and southeast were only 20-30 m above sea level (Funder and Hansen, 1996). Before $7.5 \mathrm{ka}$ BP the present state of glaciation had been attained in most parts. After this, the margins withdrew behind their present location, possibly as much as $40 \mathrm{~km}$ in some areas (Weidick, 1993). The area uncovered during the first phase of deglaciation, i.e. the clearance of the shelf, amounted to c. 0.8 million $\mathrm{km}^{2}$, while the second phase, i.e. melting and calving in fjords, uncovered only c. 0.4 million $\mathrm{km}^{2}$. This is an expression of the ice sheet's remarkable stability.

Pollen and other climate proxies show that cooling began at c. 5.5 ka BP (Funder and Fredskild, 1989) and relative sea level curves show that at this time uplift changed to subsidence due to increased ice loading (Sparrenbom et al., 2006). The culmination was reached between c. 1880 and 1925 AD, although the event was

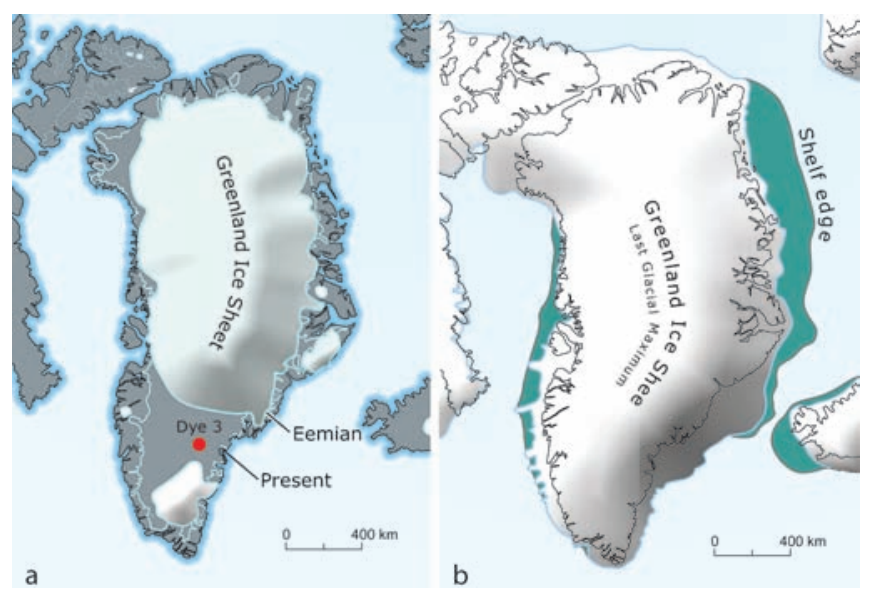

Figure 2 The Greenland ice sheet extent. (a) Minimum ice extent: among several models, this is the smallest-option for the Eemian. It is presupposed that $3.4 \mathrm{~m}$ of Eemian "excess sea level" came from Greenland. The site of the Dye 3 ice core (red dot) was earlier considered to have been ice free in the Eemian, but recent DNA studies indicate that it was ice covered; adapted from Otto-Bliesner et al. (2006). (b) Ice extent at the LGM (c. $15 \mathrm{ka} \mathrm{BP})$, based mainly on field observations and bathymetrical, seismic and coring evidence from the shelf. The blue color denotes shelf areas which may have been dry land; adapted from Ehlers and Gibbard (2004). not time-synchronous. Thereafter, glaciers began to retreat again in most parts and marked retreat phases occurred between 1925 and 1940 and since 1995 (Weidick, 1996; Wake et al., 2007).

\section{Quaternary history of a volcanic island}

Iceland has a Late Cenozoic record of glaciations starting in the Pliocene, more than $3 \mathrm{Ma}$ ago. Signatures of at least 20 glaciations are preserved in Iceland's stratigraphy, due to continuous volcanism; during glaciations, till was deposited and during interglacials, sediments accumulated in basins and soils developped on top of till beds. Interglacial lava flows capped the sediments and preserved it from erosion. A key site at Tjörnes contains strata that span the PliocenePleistocene transition. The 1,200 m thick sequence of lavas and sediments contains 14 glacial horizons of tills, as well as marine-to-littoral regression sediments, lake sediments and soils (Figure 3). The Tjörnes record shows that glacial conditions first occurred in coastal north Iceland about $3 \mathrm{Ma}$, and that ice sheets large enough to reach outside the present coast developed after 2.5 Ma (Geirsdóttir and Eiríksson, 1994; Buchard and Símonarson, 2003). Apart from the stratigraphical evidence for repeated growth of ice sheets since late Pliocene, the Icelandic landscape bears witness to the action of glaciers through time: glacially eroded valleys and fjord troughs characterize coastal western, northern and eastern Iceland, whereas hyaloclastite ridges and Table Mountains signify subglacial volcanism during periods of extensive Quaternary glaciations.

During the LGM Iceland was covered by an ice sheet that reached out towards the shelf break (Figure 4), as shown by a number of marine geological and seismostratigraphical studies (Andrews et al., 2000). It was drained by large ice streams entering major fjords and bays around the island (Hubbard et al., 2006). Ice thickness over the central highlands is not well known, but geomorphic and volcanologic data suggest maximum thicknesses of $1500 \pm 500 \mathrm{~m}$. Nunataks occurred in coastal areas on northern and eastern Iceland. Available data indicate an onset of deglaciation starting before $16 \mathrm{ka}$

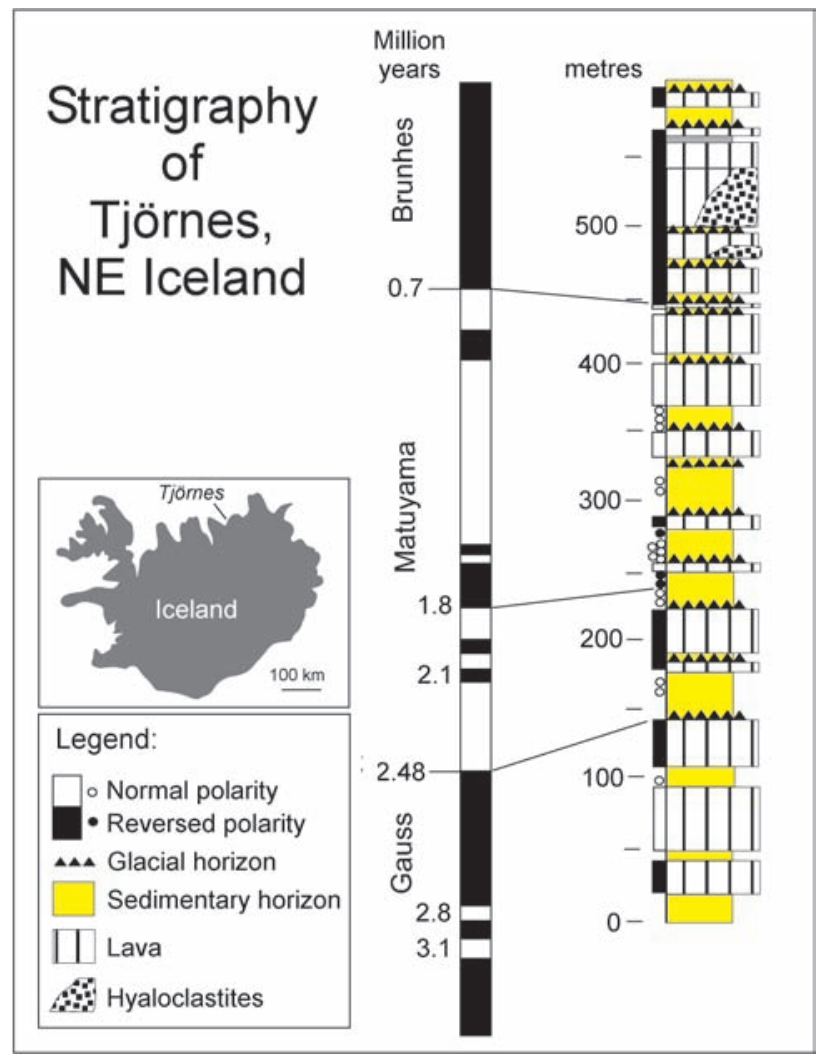

Figure 3 Stratigraphy of Tjörnes in northern Iceland showing 14 glacial horizons since 2.5 MA, modified after Einarsson (1968). 


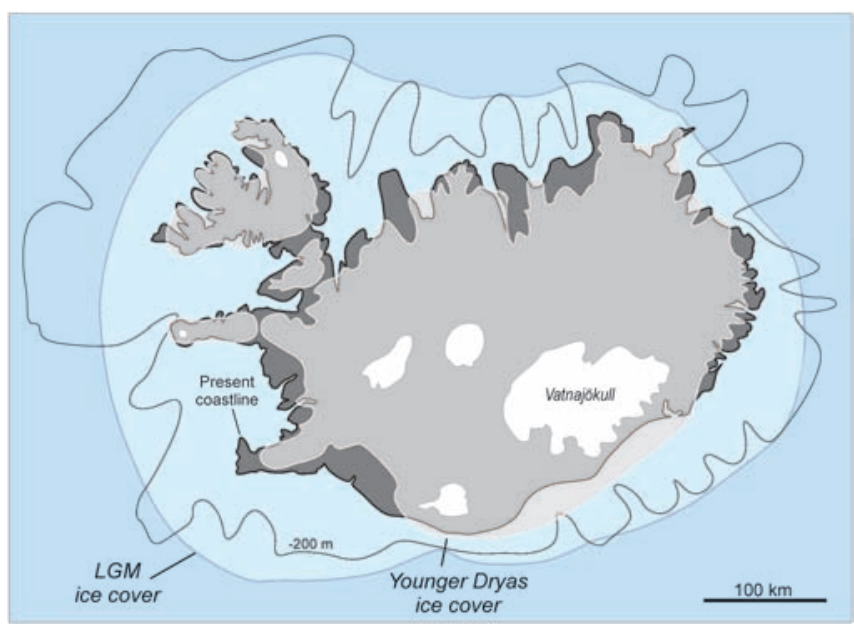

Figure 4 Extent of the Icelandic ice sheet at LGM and Younger Dryas modified after Hubbard et al. (2006).

BP off northern Iceland and c. $15.4 \mathrm{ka}$ BP off western Iceland. After 15.4 ka BP deglaciation was extremely rapid, and probably controlled by rapidly rising global sea levels causing the ice sheet to destabilize and collapse (Syvitski et al., 1999; Ingólfsson and Norddahl, 2001). By $13.8 \mathrm{ka} \mathrm{BP}$, the ice fronts were within the present coastline of Iceland. Relative sea level stood at the marine limit in western Iceland, at $150 \mathrm{~m}$ a.s.l. at c. $15 \mathrm{ka} \mathrm{BP}$, but was followed by a rapid regression as Iceland's oceanic crust rebounded quickly in response to decreased glacial loading (Norddahl and Pétursson, 2005). Once inside the coast the ice sheet started growing again, culminating in a significant Younger Dryas advance. Ice sheet growth was accompanied by a transgression which culminated at c. $12.1 \mathrm{ka}$ BP. After a brief early Preboreal (c. 11.2 ka BP) glacial advance, accompanied by a few meters of transgression in the coastal areas, the ice sheet disintegrated rapidly and glaciers were at or within present glacier limits prior to 9 ka BP (Björck et al. 1997; Rundgren et al., 1997; Norddahl and Pétursson, 2005). Due to the extremely rapid isostatic rebound, Iceland has been subject to a Holocene transgression since c. 10.2 ka BP (Ingólfsson et al., 1995).

\section{Quaternary ice sheets formed the face of Scandinavia-examples from Norway}

Quaternary glaciations formed the beautiful landscape in western Norway, including the spectacular deep fjords (e.g. Sognefjord, $1305 \mathrm{~m}$ b.s.l.). Including down-cutting above sea-level, the glacial erosion amounted to $2 \mathrm{~km}$ in several places along Norwegian fjords. Glacial erosion products were deposited as large wedges along the continental margin and as thick beds in the North Sea and DenmarkGermany. The Scandinavian Ice Sheet, which grew out from the mountain chain along the Norwegian-Swedish border, expanded some 40-50 times during the last 2.6 Ma (Mangerud 2004). During periods of maximum extent (Figure 5) it coalesced with the British, Barents Sea, Svalbard and Kara Sea ice sheets to form an Eurasian Ice Sheet, almost reaching the Black Sea (Svendsen et al., 2004).

Two types of major glacial depressions are recognized on the shelf (Figure 6). Transverse troughs, normally over-deepened to $400-500 \mathrm{~m}$ in their inner reaches, are most often seaward extensions of fjords. The longitudinal channels generally follow the boundary

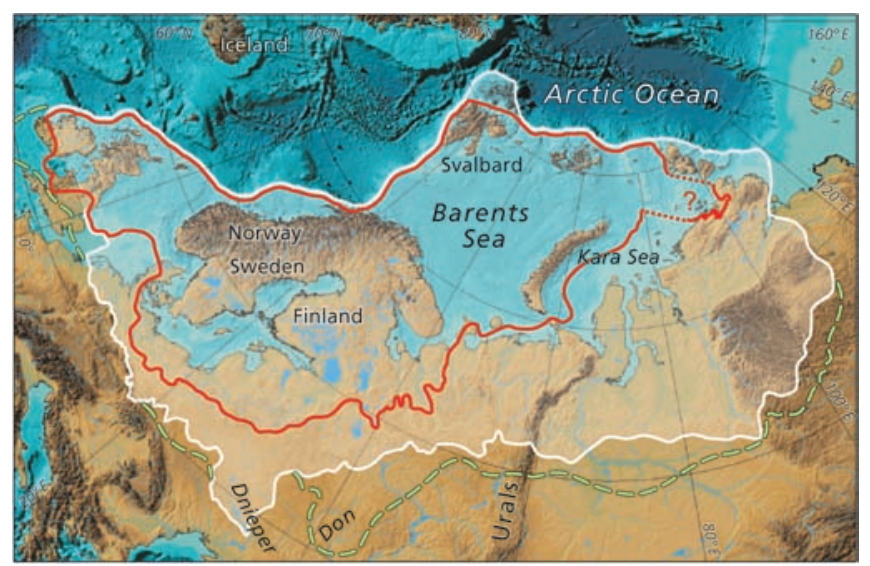

Figure 5 The Eurasian Ice Sheet during the Saalian (white), the Last Glacial Maximum (red line), and maximum extension before the Saalian (stipled green), modified after Svendsen et al. (2004).

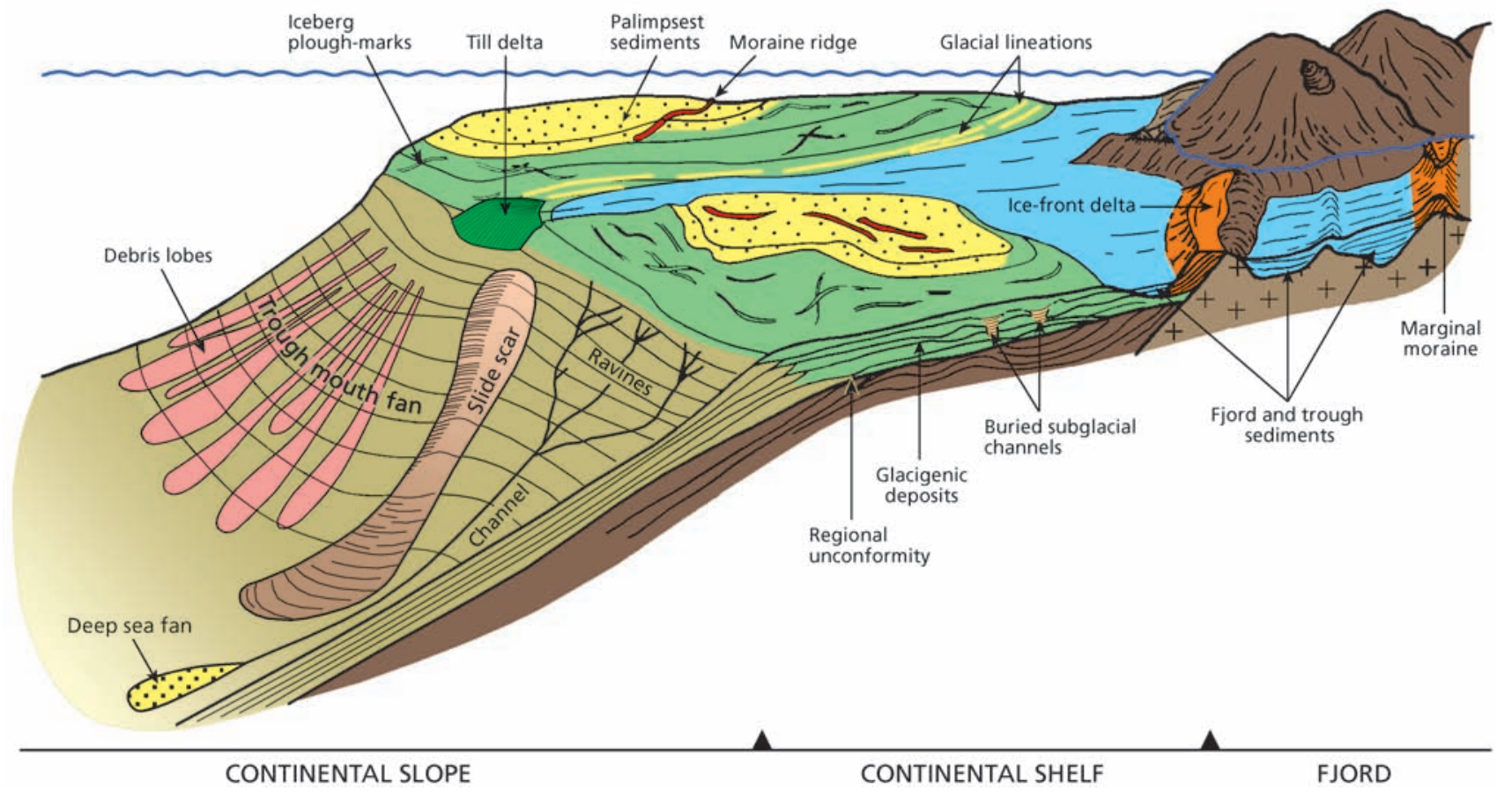

Figure 6 Model showing the main glacigenic morphological elements and lithofacies of the Norwegian continental margin, exemplified by the margin off of northern Norway; modified after Vorren and Mangerud (2006). 
between sedimentary rocks on the shelf and crystalline rocks on the coast. Channels and troughs acted as drainage routes for ice streams (e.g., Vorren and Laberg, 1997; Sejrup et al., 1996; Ottesen et al., 2005). Mega-scale lineations, from hundreds of meters to several tens of kilometers in length, show former pathways for fast-flowing ice streams; the two largest were the Norwegian Channel ice stream and the Bear Island Trough ice stream, each 150-200 km wide at the mouth. Iceberg plough marks (normally at depths of less than $500 \mathrm{~m}$ ) and iceberg turbate are found in many areas on the shelf, whereas morphological elements such as moraine ridges, lineations and glacitectonic forms (Figure 7) are similar to those found on land.

The thickness of glacigenic sediments varies between 0 and c. $300 \mathrm{~m}$ on the shelf. Much thicker prograding wedges were deposited along the continental margin, resulting in a shelf break migration of up to $150 \mathrm{~km}$. Off mainland Norway, this growth was largely a response to Quaternary glaciations during the last c. 2.5 Ma. A major change in sediment transport routes is recorded at 0.8-1.1 Ma, reflecting larger Scandinavian ice-sheets. In the western Barents Sea an early phase of wedge growth was (glacio-) fluvial in character (Dahlgren et al., 2005). Particularly large accumulations are found in the trough mouth fans that contain up to $4 \mathrm{~km}$-thick packages of glacigenic sediments, including glacimarine debris flow deposits of $2000 \mathrm{~km}^{3}$, with a run-out distance of up to $200 \mathrm{~km}$. The debris flows consist of remobilized sediments from till deltas/ grounding-zone wedges deposited by ice streams at the shelf break. The long run-out distance might be due to hydroplaning. On the steeper continental slopes, the glacigenic sediments might have been transported directly to the deep-sea by turbidity currents, through channels, and accumulated in deep-sea fans and/or drifts.

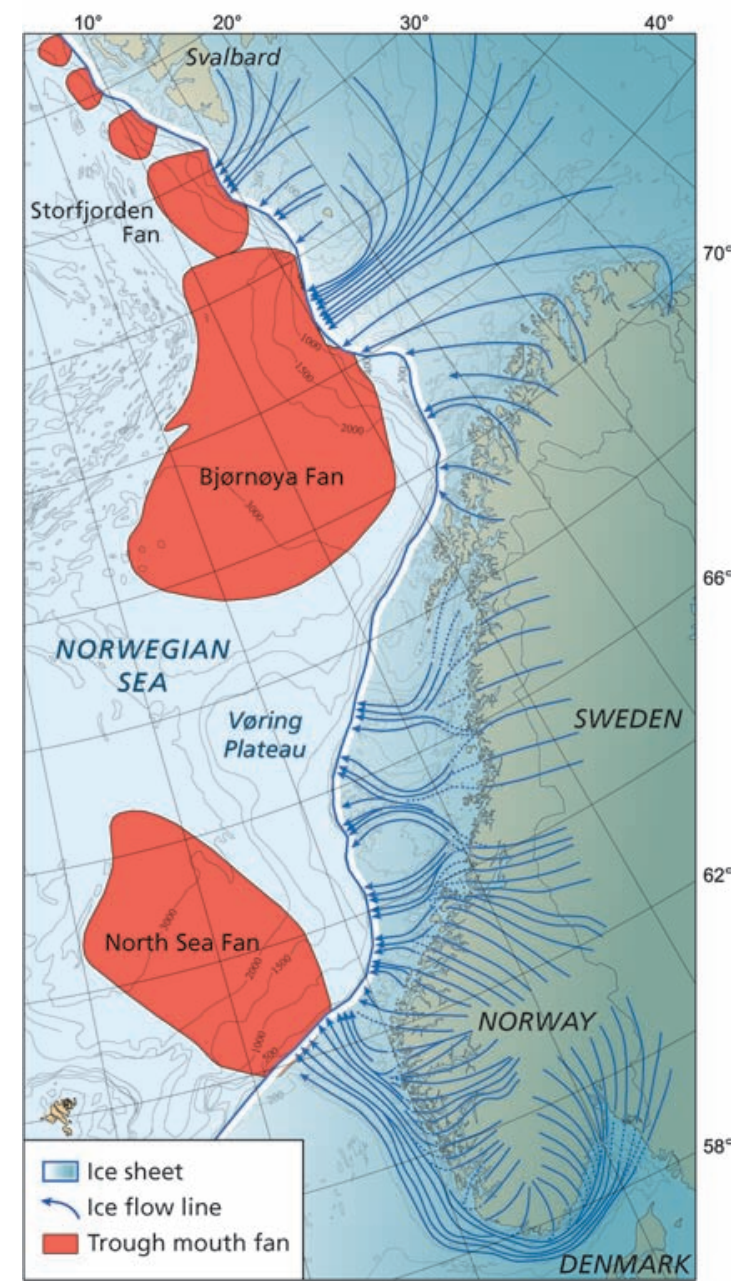

Figure 7 Inferred ice flow pattern, location and extent of trough mouth fans during large ice ages on the Norwegian continental margin, modified after Vorren and Mangerud (2006).

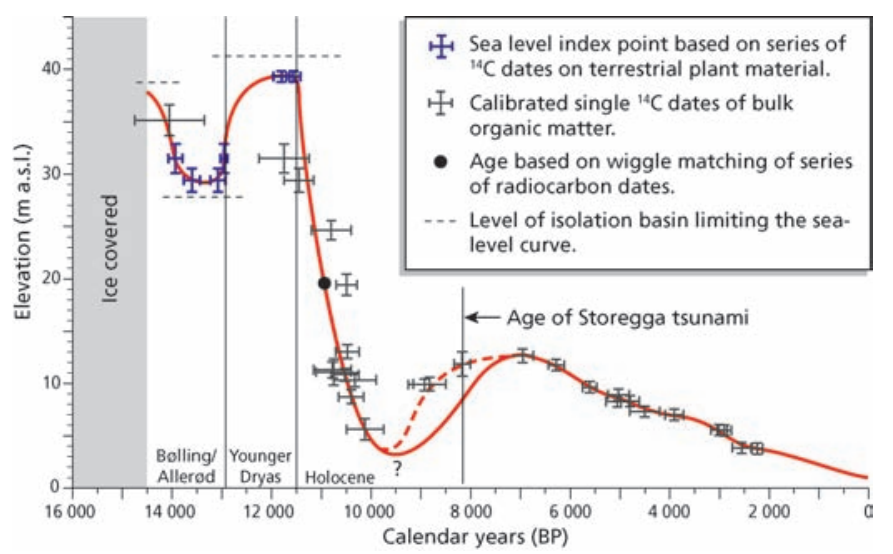

Figure 8 A sea level curve for the last $15 \mathrm{ka} \mathrm{BP}$ from the island of Sotra, west of Bergen showing $40 \mathrm{~m}$ emergence interrupted by two periods of relative sea level rise. Modified from Lohne et al. (2007).

The glaciations triggered a number of processes leading to sealevel changes. In Scandinavia, there are unique possibilities to describe these in great accuracy for the post-glacial period, because numerous lake basins have bedrock thresholds. When sea level was above the threshold, marine sediments were deposited in the basin; when high tides just reached the threshold, brackish sediments were deposited, and when sea level was even lower fresh water sediments were deposited. By coring the lake and dating the brackish sediments a sea level index point is obtained, i.e., the age and altitude of a certain sea level at the site, and by investigating lakes at different altitudes a relative sea- level curve can be constructed. An example from western Norway is shown in Figure 8 (Lohne et al., 2007).

Following the deglaciation, sea level dropped due to onset of glacio-isostatic rebound. Halt in rebound and rise in the local geoid level, both forced by a glacial re-advance, led relative sea level to move up during the Younger Dryas, followed by a fast drop at the onset of the Holocene. Many lake basins were inundated by the Storegga tsunami ( $8.2 \mathrm{ka} \mathrm{BP})$ which was created by the huge Storegga slide on the continental margin off western Norway (Bondevik et al., 1997). The Tapes transgression, reaching its maximum level at $7 \mathrm{ka} \mathrm{BP}$, was caused by deglaciation in Antarctica and/or North America, and subsequently glacio-isostatic rebound slowly caused regression to the present shore line.

\section{Interstadial lakes and shallow arctic seas: gateways for ice streams in SW- Scandinavia}

The Weichselian ice age repeatedly experienced rapid, high amplitude climatic changes between sudden warming events (interstadial conditions) followed by gradual cooling and a return to cold, stadial conditions. A number of so-called Greenland Interstadials which occurred at the beginning of longer cooling trends are registered during Marine Isotope Stage (MIS) 3 and have been correlated to the North European climate record.

In contrast to numerical models of the evolution of the Scandinavian Ice Sheet (SIS), stratigraphic evidence indicates at least four glacial advances between (MIS) 4 and 2 (Houmark-Nielsen, 2007, Houmark-Nielsen and Kjær, 2003). Clast provenances in tills indicate glacier flow twice via the Baltic Basin and twice via the Skagerrak-Kattegat trough (Figure 9). Rapid flowing ice in land based sectors of the SIS, which reached far south of the glaciated uplands, could have been initiated by the development of an expanded zone of basal melting beneath a steep gradient ice sheet. Instability, which was enhanced by melt water, caused ice-bed decoupling over large areas and may eventually have led to marginal collapse and surging through soft, water-saturated sediments bordering the SIS (Houmark-Nielsen, 2003; Kjær et al., 2003). Fine-grained freshwater 


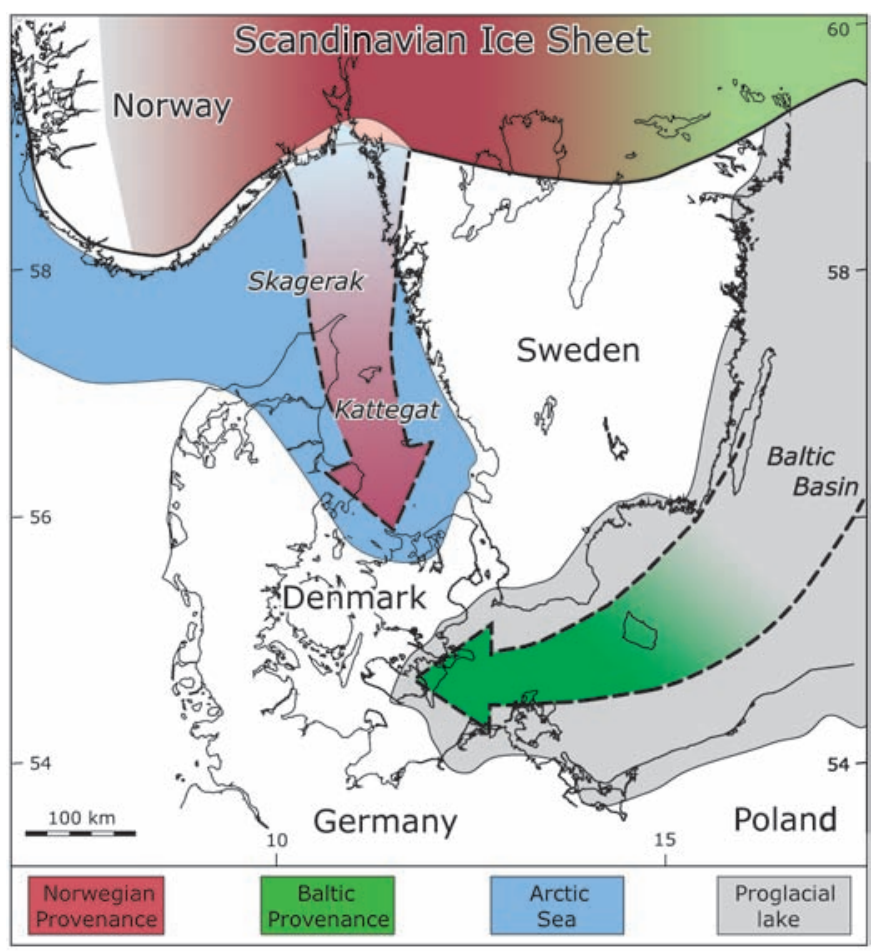

Figure 9 Distribution of shallow arctic seas and proglacialinterstadial lakes in southern Scandinavia. Arrows indicate ice streaming of Norwegian and Baltic provenance.

and marine sediments with an interstadial flora and fauna were deposited during MIS 3 in ice dammed lakes and narrow fjords in the Baltic Basin and the Kattegat trough. The regional distribution of former land-based ice streams in southern Scandinavia and in the North European lowlands seems closely related to the location of such an easily deformable substrate. The ice marginal collapse and out flow of streaming ice could have been triggered by abrupt warming, which was responsible for an ameliorated climate during MIS 3, when low arctic terrestrial biota and boreal-arctic marine waters occupied north-western Europe.

When Northern Hemisphere ice sheets experienced their largest expansion during MIS 4 and 2, slow and steady inter-stream flow was draining the SIS in central and southern Sweden, while prior to and just afterwards, rapid and canalized land-based ice streams were flowing along the Skagerrak-Kattegat trough and the Baltic depression respectively. Glaciation chronologies suggest that ice streaming occurred under relatively high glacio-eustatic sea level and ameliorated climate and that streaming episodes seem to have been out of phase with the global ice volume evolution, but might have been synchronous with regional climate trends. Alternatively, ice streaming could have been caused by internal ice sheet dynamics, which operated independently or out of phase with North Atlantic climate forcing.

\section{Scandinavian Ice Sheet history in Finland and NW Russia}

The bedrock of Finland consists almost entirely of Precambrian crystalline rocks upon which there is a relatively thin cover of mainly glacial Quaternary sediments. Stratigraphic and geochronological investigations of sediments deposited during the Eemian interglacial (c. 130-116 ka BP) and the following Weichselian (116-11.5 ka BP) make it possible to reconstruct a relatively detailed history of the major events that took place during the last interglacial/glacial cycle (Saarnisto and Lunkka, 2004). The extensive Saalian glaciation caused a strong glacio-isostatic depression which led to an open sea connection between the Baltic and White Sea

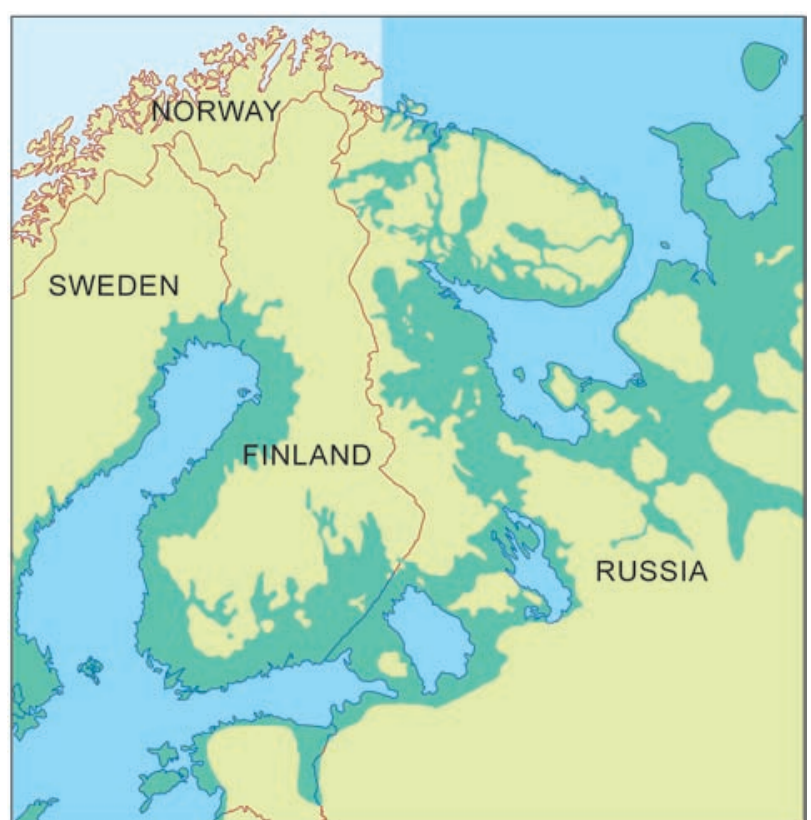

Figure 10 The extent of the Eemian Sea at around $120 \mathrm{ka} \mathrm{BP}$ between the Baltic and White Sea basins, modified after Saarnisto et al. (2002).

basins during the Eemian interglacial (Figure 10). Marine Eemian clays beneath Weichselian till have been discovered in many localities. Their pollen and diatom content indicates that the passage between the White Sea and the Baltic Sea persisted for several thousand years (Ikonen and Ekman 2001, Miettinen et al., 2002), while mollusc data suggest only a short period of true marine conditions (Funder et al., 2002).

Subsequent to the Eemian Interglacial, ice began to build up in the Scandinavian mountains and the SIS eventually spread into adjacent areas to the east and northeast (Figure 11). It covered northern Finland and eastern Lapland at c. 90 ka BP (Lunkka et al., 2004; Helmens et al., 2007), while southern and central Finland remained ice free during the entire Early Weichselian (c. 116-74 ka BP) (Saarnisto and Lunkka, 2004). After the Odderade interstadial (MIS 5a), the ice sheet started to grow again and extended across Finland towards the east and southeast. It obtained its largest extent around

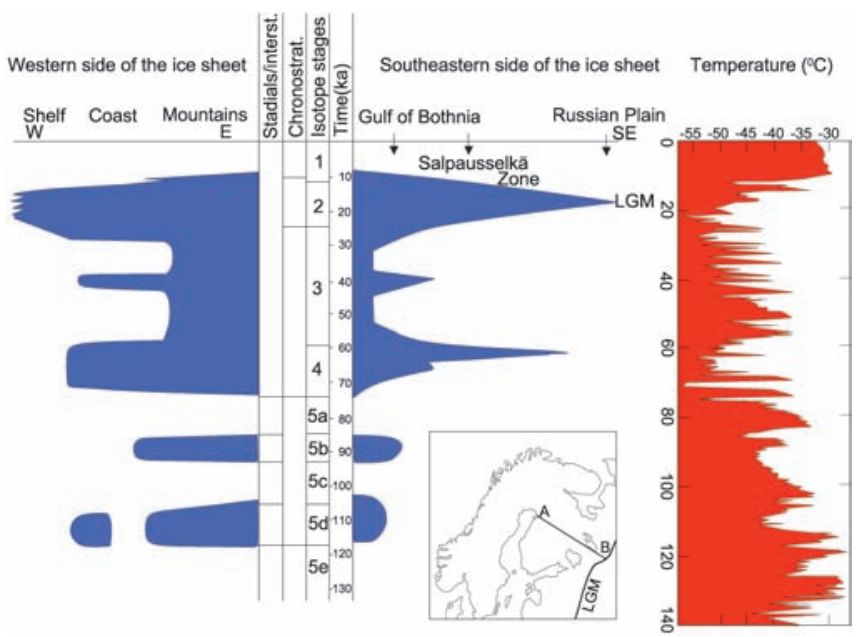

Figure 11 Time-distance diagram from the Gulf of Bothnia (A) to the Vologda area $(B)$ and from the Scandinavian mountains to the Norwegian Shelf (see inset map) showing the fluctuations of the Scandinavian Ice Sheet during the Weichselian. Greenland ice core temperature reconstructions (according to Johnsen et al., 2001) are also shown for comparison; modified after Saarnisto and Lunkka (2004) and Mangerud (2004). 
65-60 ka BP when present-day Finland was entirely ice covered (Saarnisto and Lunkka, 2004). Deglaciation commenced around $55 \mathrm{ka} \mathrm{BP}$ and periglacial conditions prevailed in southern and central Finland and even in eastern Finnish Lapland between c. 40 and $25 \mathrm{ka}$ BP (Lunkka et al., 2001, 2004, Helmens et al., 2007). The final and relatively rapid advance of the SIS took place during the Late Weichselian, when Finland and an extensive area in northwest Russia became ice covered in less than 10 ka between 25 and $17 \mathrm{ka}$ BP (Lunkka et al., 2001). Within the present dating resolution, the fluctuations of the eastern flank of the Scandinavian ice sheet were in phase with fluctuations that took place along the western flank of the ice sheet in Norway (Saarnisto and Lunkka, 2004).

Deglaciation of the eastern flank of the SIS was rapid and completed in less than $10 \mathrm{ka}$ (Saarnisto and Lunkka, 2004). The deglaciation can be traced by an analysis of glacial landforms, especially end moraines and eskers. The most remarkable and distinct Younger Dryas (12.6-11.5 ka BP) end moraine zone comprises the Salpausselkä end moraines in Finland and their correlatives in Russian Karelia, the Keiva moraines on the Kola Peninsula and the end moraines around the Norwegian coast and in central Sweden (Andersen et al., 1995).

\section{The Baltic Sea development -a review}

Nordic Quaternary geology is tightly linked with the development of the Baltic Sea because of an intricate interplay between glacial eustasy and isostasy. The Baltic Sea history is well known since the last deglaciation (Björck, 1995), but only little information exists for earlier time periods, with the exception of the last interglacial (Eem, 128-115 ka BP), when a connection, via Karelia, existed between the Baltic Sea and the White Sea during the initial part of the Eemian (Funder et al., 2002 ).

The first Baltic Sea stage, the Baltic Ice Lake, came into existence shortly after southernmost Sweden became ice free. It developed in front of the melting ice margin and received melt water from the decaying ice sheet as well as from large proglacial rivers. The outlet of the Baltic Ice Lake was situated in the Öresund region, where thick glacial deposits covered the chalk bedrock. The out-flowing water easily eroded the threshold and cut gradually deeper into the glacial deposits as the threshold kept rising. Around $14 \mathrm{ka} \mathrm{BP}$, the out-flowing water had eroded most of the glacial deposits down to the flint dominated bedrock. The cessation of the erosion, combined with isostatic uplift in the Öresund region being larger than the sea level rise, led to a shallowing of the threshold. This caused a damming up of the Baltic Ice Lake, a transgression in the southernmost part of the Baltic, and a reduced regression in the remainder of the basin. At $\mathrm{c}$. $13 \mathrm{ka} \mathrm{BP}$, the ice margin was situated at the southern margin of the south-central Swedish low-land area (Figure 12a). The elevation of this area was, because of the isostatic depression, considerably lower than the threshold in the Öresund region, and the Baltic Ice Lake was dammed up 5-10 $\mathrm{m}$ a.s.l. Deglaciation of this southern margin at the water divide (Mt. Billingen) led to this first, poorly documented, drainage of the Baltic Ice Lake, with a new pathway for the waters towards the west. This may have lowered the level of the Baltic by 5-10 $\mathrm{m}$ and created a land bridge between Denmark and Sweden in the former outlet area in Öresund. The immigration of plants and animals to southern Sweden was facilitated, and the Baltic Ice Lake waters continued to drain westwards through the low-land area in south-central Sweden for another 300-400 years. Around $12.8 \mathrm{ka}$
BP, at the start of the Younger Dryas cold period, the ice front started to re-advance and finally "closed" the connection between the sea in the west and the Baltic in the east. Meanwhile, the former threshold in the Öresund had risen even higher above sea level. The Baltic basin was once more dammed up above sea level. Towards the end of the Younger Dryas period, the level of the Baltic Ice Lake was 25 $\mathrm{m}$ higher than sea level, dammed up by the rising Öresund threshold in the south. A slight warming trend at around $12 \mathrm{ka} \mathrm{BP}$ caused the ice sheet to start retreating again. This led to a sudden and rapid drainage of the Baltic Ice Lake at Mt. Billingen through the southcentral Swedish lowlands at $11.7 \mathrm{ka}$ BP. Detailed studies have shown that the water level in the Baltic Ice Lake dropped by $25 \mathrm{~m}$ within only $1-2$ years with the release of $7000-8000 \mathrm{~km}^{3}$ of water (Jakobsson et al., 2007) producing large lobes of drainage deposits west of Mt. Billingen. The drainage led to distinct changes in the south western part of the Baltic, where the area around the former land bridge between Denmark and Sweden had increased in size. This land bridge facilitated a rapid immigration of plants and animals and humans into southern Sweden at the beginning of the Holocene. The rapidly melting ice sheet in south-central Sweden and the isostatically depressed areas in south central Sweden later allowed incursion of marine waters towards the east.

The second Baltic Sea stage (Figure 12b), the Yoldia Sea (11.6-10.7 ka BP) started once the Baltic had reached sea level; it is 
named after the glaciomarine shell Portlandia (Yoldia) arctica, which has been found in sediments in south-central Sweden. During a few hundred years in the middle of this stage, saline water reached as far as Finland and the southern Baltic. Rapid land uplift in southcentral Sweden led to a shallowing of the connecting sounds and the Yoldia Stage came to an end. Drainage from the Baltic to the west coast was through Lake Vänern and further west through two river valleys. However, the rapid uplift of these outlets finally led to a new damming stage of the Baltic, the so-called Ancylus Lake Stage (10.7-9.8 ka BP), named after the freshwater snail Ancylus fluviatilis (Figure 12c, d). Since the Baltic level was regulated by uplift of the outlet area west of Lake Vänern, areas south of this isobase i.e. from southwestern-most Finland and southwards experienced a transgression; the further south the more extensive was the transgression, reaching a maximum of c. $20 \mathrm{~m}$. The highest water level of the Ancylus Lake stage, which also marks the end of the Ancylus transgression, is today visible as distinct beach ridges on both sides of the Baltic. A sudden fall of the Ancylus Lake at $10.3 \mathrm{ka} \mathrm{BP}$, the Ancylus regression, implies that erosion had created a new outlet, most likely through the German-Danish area, Darss Sill-Fehmarn Belt-Great Belt, where a large fluvial-lacustrine system was established around this time. The first signs of salt water in the Baltic, at around $9.8 \mathrm{ka}$ BP, mark the end of the Ancylus Lake stage and show that marine water occasionally was able to penetrate through the long fluvial system in the Denmark, the so-called Dana River.

The last Baltic Sea stage, the Littorina Sea, named after the mollusc Littorina littorea, leads over to the present day Baltic Sea. From this time onwards, relative sea level changes were only governed by global sea level and local land uplift, but it would take at least another millennium before it became a truly brackish sea. During the early Littorina Sea stage land areas in the southern Baltic experienced a transgression, because there land uplift had ceased. Around 9.0-8.5 ka BP the sea level rise became more rapid than uplift in southern Sweden and coastal areas became transgressed, and transgression of the Öresund threshold $(-7 \mathrm{~m})$ allowed more marine water to enter the Baltic. During the following 3000 years five different transgression periods are recognized in the southern Baltic and have been related to global sea level changes as a consequence of melting of remaining ice sheets. The salinity of the Littorina Sea reached maxima during these transgressions and the concomitant high productivity led to oxygen deficiency in the bottom waters. Recurrent oxygen deficiency has been linked to increased salt water ingression and an often warmer environment, while colder conditions led to decreased salt content in the Baltic Sea waters. Since c. $5 \mathrm{ka}$ BP the Baltic Sea level is only determined by the apparent uplift, highest today in northern Sweden with $8-9 \mathrm{~mm} / \mathrm{yr}$ and lowest in the very south with $-1 \mathrm{~mm} / \mathrm{yr}$.

\section{References}

Andersen B.G., Lundqvist J., and Saarnisto M., 1995, The Younger Dryas margin of the Scandinavian Ice Sheet - An Introduction: Quaternary International, v. 28, pp. 145-146.

Andrews, J.T., Hardardóttir, J., Helgadóttir, G., Jennings, A.E., Geirsdóttir, A., Sveinbjörnsdóttir, A.E., Schoolfield, S., Kristjánsdóttir, G.B., Smith, L.M., Thors, K., and Syvitski, J., 2000, The N and W Iceland Shelf: Insights into Last Glacial Maximum ice extent and deglaciation based on acoustic stratigraphy and basal radiocarbon AMS dates: Quaternary Science Reviews, v. 19, pp. 619-631.

Bennike, O., and Björck, S., 2002, Chronology of the last recession of the Greenland Ice Sheet: Journal of Quaternary Science, v. 17, pp. 211-219.

Björck, S., 1995, A review of the history of the Baltic Sea 13,0 to 8,0 ka BP: Quaternary International, v. 27, pp. 19-40.

Björck, S., Rundgren, M. Ingólfsson, Ó., and Funder, S., 1997, The Preboreal oscillation around the Nordic Seas: terrestial and lacustrine responses: Journal of Quaternary Science, v.12, pp. 455-465.

Bondevik, S., Svendsen, J.I., Johnsen, G., Mangerud, J., and Kaland, P.E., 1997, The Storegga tsunami along the Norwegian coast, its age and runup: Boreas, v. 26, pp. 29-53.
Buchard, B., and Símonarson, L., 2003, Isotope paleotemperatures from the Tjörnes beds in Iceland: evidence of Pliocene cooling: Palaeogeography, Paleaoclimatology, Palaeoecology, v. 189, pp. 71-95.

Cape-Last Interglacial Project Members, 2006, Last Interglacial Arctic warmth confirms polar amplification of climate change: Quaternary Science Reviews, v. 25, pp. 1383-1400.

Dahlgren, K.I.T., Vorren, T.O., Stoker, M., Nielsen, T., Nygård, A., and Sejrup, H.P., 2005, Late Cenozoic prograding wedges on the NW European continental margin: their formation and relationship to tectonics and climate: Marine and Petroleum Geology, v. 22, pp. 1089-1110.

Denton, G.H., Alley, R.B., Comer, G.C., and Broecker, W.S., 2005, The role of seasonality in abrupt climate change: Quaternary Science Reviews, v. 24, pp. 1159-1182.

Eldrett, J.S., Harding, I.C., Wilson, P.A., Butler, E., and Roberts, A.P., 2007 Continental ice in Greenland during the Eocene and Oligocene: Nature v. 446, pp. 176-179

Ehlers, J., and Gibbard, P. (eds), 2004, Quaternary glaciations, extent and chronology II. Elsevier: Amsterdam, 488 pp.

Funder, S., Bennike, O., Böcher, J., Israelson, C., Petersen, K.S., and Símonarson, L.A., 2001, Late Pliocene Greenland - The Kap København Formation in North Greenland: Bulletin of the Geological Society of Denmark, v. 48, pp. 117-134.

Funder, S., and Fredskild, B., 1989, Paleofaunas and floras (Greenland), in Fulton, R.J., ed, Quaternary geology of Canada and Greenland. Geological Society of America, The Geology of North America K- 1, pp. 775-783.

Funder, S., and Hansen, L., 1996, The Greenland ice sheet - a model for its culmination and decay during and after the last glacial maximum: Bulletin of the Geological Society of Denmark, v. 42, pp. 137-152.

Funder, S., Jennings, A., and Kelly, M. 2004, Middle and Late Quaternary glacial limits in Greenland, in Ehlers, J., and Gibbard, P., eds, Quaternary glaciations, extent and chronology II, Elsevier, Amsterdam, pp. 425-430.

Funder, S., Demidov, I., and Yelovicheva, Y., 2002, Hydrography and mollusc faunas of the Baltic and White Sea - North Sea seaway in the Eemian: Palaeogeography, Palaeoclimatology, Palaeoecology, v. 184, pp. 275-304.

Geirsdóttir, A., and Eiríksson, J., 1994, Growth of an intermittent ice sheet during the late Pliocene and early Miocene: Quaternary Research, v. 42, pp. $115-130$.

Helmens, K.F., Johansson, P.W., Räsänen, M.E., Alexanderson, H., and Eskola, K.O., 2007, Ice-free intervals continuing into Marine Isotope Stage 3 at Sokli in the central area of the Fennoscandian glaciations: Bulletin of the Geological Society of Finland, v. 79, pp. 17-39.

Houmark-Nielsen, M, 2003, Signature and timing of the Kattegat Ice Stream: onset of the LGM sequence in the southwestern part of the Scandinavian Ice Sheet: Boreas, v. 32, pp. 227-241.

Houmark-Nielsen, M., 2007, Extent and age of Middle and Late Pleistocene glaciations and periglacial episodes in southern Jylland, Denmark: Bulletin of the Geological Society of Denmark, v. 55, pp. 9-35.

Houmark-Nielsen, M, and Kjær, K., 2003, Southwest Scandinavia, 40-15 kyr BP: paleogeography and environmental change: Journal of Quaternary Science, v. 18, pp. 769-786.

Hubbard, A., Sugden, D.A., Dugmore, A., Norddahl, H., and Pétursson, H.G., 2006, A modelling insight into the Icelandic Last Glacial Maximum ice sheet: Quaternary Science Reviews, v. 25, pp. 2283-2296.

Ikonen L, and Ekman I., 2001, Biostratigraphy of the Mikulino interglacial sediments in NW Russia: the Petrozavodsk site and a literature review: Annales Academiae Scientiarum Fennicae A III, Geologica-Geographica, v. 161 , pp. $1-88$

Ingólfsson, Ó, Norddahl, H., and Haflidason, H., 1995, A rapid isostatic rebound in South-western Iceland at the end of the last glaciation: Boreas, v. 24 , pp. $245-259$.

Ingólfsson, Ó., and Norddahl, H., 2001, High Relative Sea Level during the Bölling Interstadial in Western Iceland: A Reflection of Ice-sheet Collapse and Extremely Rapid Glacial Unloading: Arctic, Antarctic, and Alpine Research, v. 33, pp. 231-243.

Jakobsson, M., Björck, S., Alm, G., Andrén, T., Lindeberg, G., and Svensson, N.-O., 2007, Reconstructing the Younger Dryas ice dammed lake in the Baltic Basin - Bathymetry, area and volume: Global and Planetary Change, v. 57 , pp. $355-370$.

Jennings, A.E., Hald, M., Smith, M., and Andrews, J.T., 2006, Freshwater forcing from the Greenland Ice Sheet during the Younger Dryas: evidence from southeastern Greenland shelf cores: Quaternary Science Reviews, v. 25, pp. 282-298.

Johnsen, S., Dahl-Jensen, D., Gunderstrup N., Steffensen, J., Clausen, H., Miller, H. Masson-Delmotte, V., Sveinbjörnsdottir, A., and White, J., 2001, Oxygen Isotope and palaeotemperature records from six Greenland icecore stations: Camp Century, Dye-3, GRIP, GISP 2, Renland and North GRIP: Journal of Quaternary Science, v. 16, pp. 299- 307.

Kjær K. H, Houmark-Nielsen M., and Richardt N., 2003, Ice-flow patterns and dispersal of erratics at the southwestern margin of the last Scandinavian ice sheet: imprint after palaeo-ice streams: Boreas, v. 32, pp. 130-148. 
Kuijpers, A., Dalhoff, F., Brandt, M.P., Hümbs, P., Schott, T., and Zotova, A., 2007, Giant iceberg plow marks at more than 1 kilometre water depth offshore West Greenland: Marine Geology, v. 246, pp.60-64.

Lohne, Ø., Bondevik, S., Mangerud, J., and Svendsen, J.I., 2007, Sea-level fluctuations imply that the Younger Dryas ice-sheet expansion in western Norway commenced during the Allerød: Quaternary Science Reviews, doi:10.1016/j.quascirev.2007.04.008.

Lunkka, J. P., Saarnisto, M., Gey, V., Demidov, I., and Kiselova, V., 2001, Extent and age of the Last Glacial Maximum in the southeastern sector of the Scandinavian Ice Sheet: Global and Planetary Change, v. 31, pp. $407-425$.

Lunkka, J. P., Johansson, P., Saarnisto, M., and Sallasmaa, O., 2004, Glaciation of Finland, in Ehlers, J., and Gibbard, P., eds, Quaternary Glaciations - Extent and Chronology, Part 1-Europe. Elsevier, Amsterdam, pp. 93-100.

Mangerud, J., 2004, Ice sheet limits on Norway and the Norwegian continental shelf. in Ehlers, J., and Gibbard, P., eds, Quaternary Glaciations-Extent and Chronology, Part 1-Europe: Elsevier, Amsterdam, pp. 271-294.

Miettinen, A., Rinne, K., Haila, H., Hyvärinen, H., Eronen, M., Delusina, I., Kadastik, E., Kalm, V., and Gibbard, P., 2002, The marine Eemian of the Baltic: new pollen and diatom data from Peski, Russia, and Pohja-Uhtju, Estonia: Journal of Quaternary Science v. 17, pp. 445-458.

Norddahl, H. and Pétursson, H.G. 2005. Relative Sea-Level Changes in Iceland; new Aspects of the Weichselian Deglaciation of Iceland, in Caseldine, C., Russel, A., Hardardottir, J. and Knudsen, O. eds, Iceland-Modern Processes and Past Environments, pp. 25-78. Elsevier, Amsterdam.

Ottesen, D., Dowdeswell, J.A., and Rise, L., 2005, Submarine landforms and the reconstruction of fast flowing ice streams within a large Quaternary ice sheet: The 2500-km-long Norwegian-Svalbard margin: GSA Bulletin, v. 117 , pp. 1033-1050.

Otto-Bliesner, B.L, Marshall, S.J., Overpeck, J.T., Miller, G.H., Hu, A., and CAPE Last Interglacial Project members, 2006, Simulating Arctic climate warmth and icefield retreat in the Last Interglaciation: Science, v. 311, pp. 1751-1753.

Rundgren, M., Ingólfsson, Ó, Björck, S., Jiang, H., and Haflidason, H., 1997, Dynamic sea-level change during the last deglaciation of Northern Iceland: Boreas, v. 26, pp. 201-215.

Saarnisto, M., and Lunkka, J. P., 2004, Climate variability during the last interglacial-glacial cycle in NW Eurasia., in Battarbee R.W., Gasse F. and Stickley C.E., eds, Past Climate Variability through Europe and Africa, Kluwer Academic Publishers, Dordrecht, the Netherlands, pp. 443-464.

Saarnisto, M., Lunkka, J. P. and Sallasmaa, O., 2002, The extent and duration of the Eemian submergence between the Baltic and the White Sea Basin. Deklim - Eem 1st Workshop March 2002, 18th -21st Leipzig - Climate change at the very end of a warm stage. Abstract volume, 47-48.

Sejrup, H.P., King, E.L., Aarseth, I., Haflidason, H., and Elverhøi, A., 1996, Quaternary erosion and depositional processes: Western Norwegian fjords, Norwegian Channel and North Sea Fan, in DeBatist, M. and Jacobs, P., eds, Geology of Siliciclastic Shelf Seas, pp. 187-202, Geological Society Special Publication 117.

Svendsen, J. I., Alexanderson, H., Astakhov, V. I., Demidov, I., Dowdeswell, J. A., Funder, S., Gataullin, V., Henriksen, M., Hjort, C., HoumarkNielsen, M., Hubberten, H. W., Ingólfsson, Ó., Jakobsson, M., Kjær, K. H., Larsen, E., Lokrantz, H., Lunkka, J. P., Lyså, A., Mangerud, J., Matiouchkov, A., Murray, A., Möller, P., Niessen, F., Nikolskaya, O., Polyak, L., Saarnisto, M., Siegert, C., Siegert, M. J., Spielhagen, R. F., and Stein, R., 2004, Late Quaternary ice sheet history of northern Eurasia, in Thiede, J., ed, Quaternary environments of the Eurasian North (QUEEN): Quaternary Science Reviews, v. 23, pp. 1229-1271.

Sparrenbom, C. J., Bennike, O., Björck, S., and Lambeck, K., 2006, Holocene relative sea-level changes in the Qaqortoq area, southern Greenland: Boreas, v. 35, pp. 171-187.

Syvitski, J., Jennings, A. E., and Andrews, J. T., 1999, High-resolution Seismic Evidence for Multiple Glaciation across the Southwest Iceland Shelf: Arctic, Antarctic, and Alpine Research, v. 31, pp. 50-57.

Vorren, T.O., and Laberg, J.S., 1997, Trough mouth fans- palaeoclimate and ice-sheet monitors: Quaternary Science Reviews, v. 16, pp. 865-881.

Vorren, T.O., and Mangerud, J., 2006, Istider kommer og går, in Ramberg, I., Bryhni, I., and Nøttvedt, A., eds, Landet blir til. Norges Geologi. pp. 478-531: Norsk Geologisk Forening.

Wake, L.M., Huybrechts, P., Janssens, I., Hanna, E., and Box, J., 2007, Surface mass balance history of the Greenland Ice Sheet (1868-2005): Geophysical Research Abstracts 9, SRef-ID: 1607-7962/gra/EGU2007-A-06835.

Weidick, A., 1993, Neoglacial change of ice cover and the related response of the Earth's crust in West Greenland: Grønlands geologiske Undersøgelse, report v. 159, pp. 121-126.

Weidick, A., 1996, Late Holocene and historical changes of glacier cover and related sea level in Greenland: Zeitschrift für Gletscherkunde und Glaziologie v. 32, pp 217-224.
Willerslev, E., Cappellini, E, Boomsma, W., Nielsen, R., Hebsgaard, M.B., Brand, T.B., Hofreiter, M., Bunce, M., Poinar, H. N., Dahl-Jensen, D., Johnsen, S., Steffensen, J.P., Bennike, O., Schwenninger, J.-L., Nathan, R., Armitage, S., de Hoog, C.-J., Alfimov, V. Christl, M., Beer, J., Muscheler, R., Barker, J., Sharp, M., Penkman, K.E.H., Haile, J., Taberlet, P., Thomas, M., Gilbert, P., Casoli, A., Campani, E., and Collins, M.J., 2007, Ancient biomolecules from deep ice cores reveal a forested Southern Greenland. Science, v. 317, pp. 111-114.

Barbara Wohlfarth is professor in Quaternary geology at Stockholm University. She obtained her MSc in geology at the University of Bern, Switzerland and her PhD at the University of Cologne, Germany and was postdoctoral fellow, assistant professor and associate professor in Quaternary geology at Lund University until 2002. Her current research addresses abrupt climatic changes and their environmental impact during the Late Quaternary and her most favorite study object are lake sediments and their hidden treasures. She has worked in Sweden, Russia, Romania, Switzerland, France, Greenland, Svalbard, Canada and Argentina.

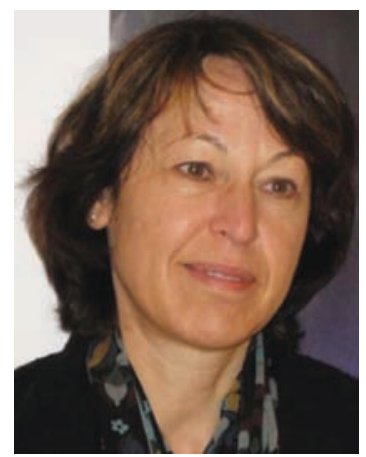

Svante Björck is professor in Quaternary Sciences at Lund University. His research addresses the climatic history of the Atlantic region during the last glacial cycle, focusing on periods with distinct climatic change and their underlying mechanisms and environmental impacts, incl. the bipolar seesaw effect, along an Atlantic transect: Greenland, Iceland, Faroe Islands, Scandinavia, Azores, Tristan da Cunha, Tierra del Fuego and Antarctic Peninsula islands. He also works with relative sea level changes in Greenland and Scandinavia and tries to unravel some mysteries of the postglacial Baltic Sea history. He is member of the Royal Swedish Academy of Sciences and has been awarded several academic prices.

\section{Svend Funder is associate professor} and senior curator at the Natural History Museum, University of Copenhagen, where he is in charge of Quaternary and palaeobotanical collections. His research interests focus on Quaternary stratigraphy and climate/environmental change throughout the Quaternary. His field work has mostly been in Arctic areas and he has spent up to 25 summers in Greenland. He is author or editor of several reviews of the Quaternary in Greenland in books and dedicated

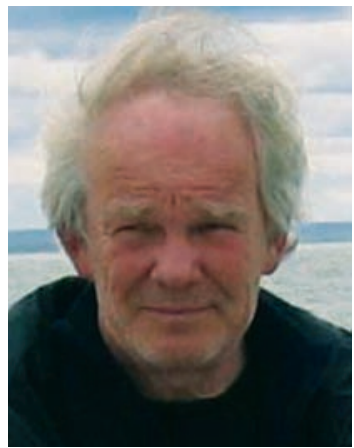
journal volumes.

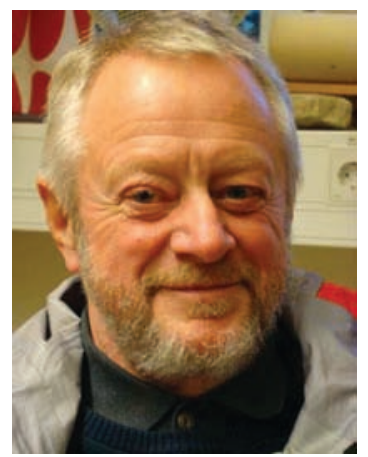


Michael Houmark-Nielsen is associate Professor in Quaternary geology at the University of Copenhagen. He has studied the sedimentology of glacial and periglacial deposits in northern Europe and the Arctic for more than twenty five years. Preferred subjects comprise Pleistocene stratigraphy, studies of the glacio-tectonic architecture in glacial landforms, the recognition of superimposed glacially sculptured terrains, the dynamics of the Scandinavian Ice Sheet and palaeo-environmental analyses of inter till deposits. The chronology of ice sheet growth and decay and palaeo-geographical reconstructions for south west Scandinavia during the last ice age are continuously being updated.

Ólafur Ingólfsson is professor in geology at the University of Iceland. He defended his PhD at Lund Unias associate professor for seven years before moving to Gothenburg University as full professor in 2000. Before returning to Iceland, he was professor of glacial and Quaternary geology at the University Centre on Svalbard (UNIS) for three years. His research has over the past 20 years been focused on the Late Quaternary glacial- and climate histories of polar regions and Iceland. versity in Sweden, where he worked

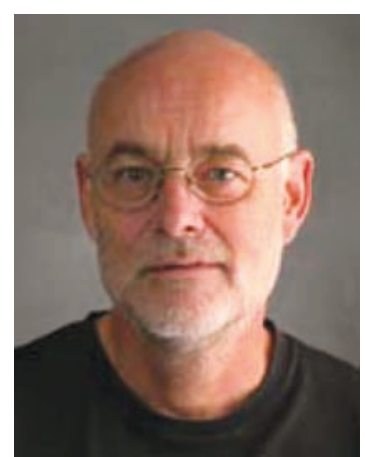

Jan Mangerud is professor emeritus at the Department of Earth Science and the Bjerknes Center for Climate Research, University of Bergen, Norway. His scientific work has mainly been on the glacial history of Norway, northern Russia and the Arctic. He is elected fellow of the Norwegian Academy of Science and Academia Europeae and Honorary member of the International Union of Quaternary Research (INQUA) and the Quaternary Research Association (QRA), Great Britain. Mangerud has been awarded the Reusch Medal and the Brogger Prize of the Geological Society of Norway and the Fram Committee Nansen Award for Polar Research.

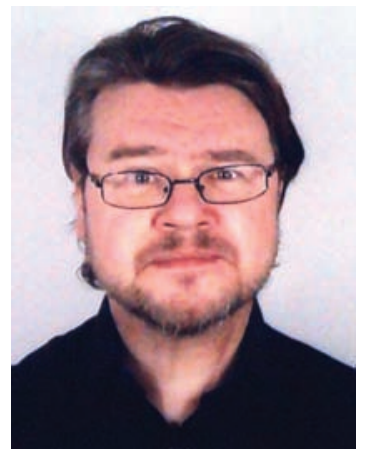

Matti Saarnisto (PhD University of Helsinki 1970) was associate professor at the University of Oulu, professor at the University of Helsinki and research director at the Geological Survey of Finland, from where he retired in 2006. His research focuses on the history of Weichselian glaciation and the Baltic Sea. His international collaboration includes the Working Group on annually laminated sediments of INQUA, IGCP Project Termination of the Pleistocene, the QUEEN and HOLIVAR Programs of the European Science Foundation. He has also been member of the scientific steering committee of IGBP-PAGES. Since 2000 he has acted as Secretary General of the Finnish Academy of Science and Letters.

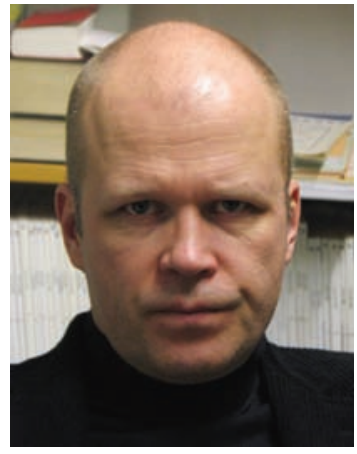

Tore O. Vorren is professor of Quaternary and marine geology at the University of Troms $\phi$. His scientific work is dedicated to the Late Cenozoic evolution of the continental margins and fjords in the Arctic sub-Arctic regions, particularly the Barents Sea, Spitsbergen and North Norway. He received his MSc degree from the University of Bergen; and his $P h D$ from the University of Troms $\phi$. Currently he is serving as dean at the Faculty of Science at the University of Troms $\phi$.
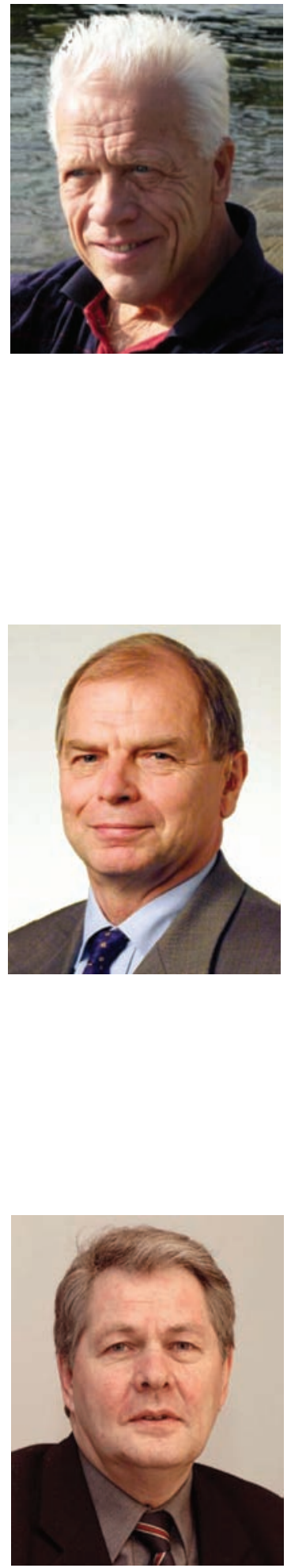
raphy of Late Pleistocene glacial and interglacial deposits in northwest Russia and Finland. 